\title{
Houston, we Have a Pandemic: Technical Difficulties, Distractions and Online Student Engagement
}

\author{
Dimitra Kostaki and Irene Karayianni \\ Psychology Department, Deree, The American College of Greece \\ For correspondence, please contact: ikarayianni@acg.edu
}

Dimitra Kostaki: D.Kostaki@acg.edu Greek-American undergraduate psychology student, currently in the 3rd year of study at Deree, the American College of Greece Irene Karayianni: ikarayianni@acg.edu_Associate Lecturer I at Deree, the American College of Greece. Currently teaching human learning \& memory, and research methods courses.

\begin{abstract}
The COVID-19 pandemic has brought a massive shift to remote education, as college students rely on technology to attend class and interact with instructors and peers, while possibly facing technical and situational difficulties at home. Considering the unprecedented situation, the purpose of the present study was to explore student engagement in a small private, American college in Greece during the COVID-19 pandemic, where classes were transitioned mid-semester to synchronous online. It was hypothesized that student engagement would be negatively correlated with both technical difficulties and home distractions. Moreover, we investigated whether computer self-efficacy would mediate the former relationship. The survey sample consisted of 78 undergraduate students, recruited online. Participants completed scales on online student engagement, technical difficulties, home distractions and computer self-efficacy, as well as two exploratory open-ended questions on their attitudes towards online classes. Student engagement was negatively correlated with both technical difficulties and home distractions, while computer self-efficacy mediated the relationship between student engagement and technical difficulties. Students reported that what they enjoyed most in e-classes were the exact aspects that interfered with their learning and engagement. The most commonly reported concern in online courses was impaired concentration and technical issues, while flexibility, time efficiency and home comfort were the aspects that students enjoyed most. The study aims to shed light on engagement in remote learning, as online classes may eventually become an integral component of higher education after the return to a so-called new normality. Suggestions to improve student engagement based on the findings are provided.
\end{abstract}

Keywords student engagement, COVID-19, distance education, distraction, computer self-efficacy

\section{Introduction}

The World Health Organization declared COVID-19 as a global public health emergency on January 30, 2020 and a pandemic on March 11 of the same year (Cucinotta \& Vanelli, 2020). COVID-19, which has caused more than 4.2 million deaths worldwide (WHO, July 2021), has brought about significant and unprecedented challenges not only in health, but in numerous sectors of life, including education. Various forms of social, educational and professional interaction moved from offline to online. On March 23, 2020 Greece was put under the first lockdown (Parlapani et al., 2020), and on November 9 under the second (Siettos et al., 2021). During fall 2020, classes were transitioned, once again, mid-semester 
from hybrid (half of the students in-person and half online, interchangeable every week) or face-to-face (F2F), to fully remote teaching mode, changing the educational landscape for most of higher education institutions, since the vast majority operate remotely (Azzi-Huck \& Shmis, 2020; Dhawan, 2020; Marinoni et al., 2020; Shahzad et al., 2020).

The health and psychological pressures caused by the pandemic brought uncertainty and challenged students' mental health in terms of heightened stress, anxiety and depressive thoughts, as shown in studies across the world: China (Cao et al., 2020; Wang \& Zhao, 2020), India (Debbarma \& Durai, 2021), the US (Gazmararian et al., 2021; Son et al., 2020) and Europe (Wirkner et al., 2021). Students' mental health and stress are negatively associated with student engagement (Steele \& Fullagar, 2009), levels of concentration and productivity (Vinkers et al., 2020) and create additional cognitive load (Ratcliff et al., 2021; Sweller, 1988) that hinders learning. However, research on how COVID-19 has impacted the educational system is still rather scarce (Bao, 2020; Sintema, 2020; Yan, 2020). Forty-one percent of undergraduates state that their good opinion of their university declined during the first COVID-19 wave and 63\% report that teaching has been impaired since the shift to remote learning (Simpson-Scarborough, 2020). Adnan and Anwar (2020) studied undergraduate students, mainly females, that were either attending online courses at the time or had finished their last semester virtually, and found that students believed it is not feasible to complete a course effectively when it is online. Similar results were reported by Garris and Fleck (2020), as courses that were transitioned to online were evaluated as having decreased enjoyment, interest, and learning value, among other dimensions of course quality. The emergency transition to online classes may have a negative impact also in students with learning disabilities (Burghstahler, 2003), as Barnard-Brak and Sulak (2010, p. 82) noted that they "can become outpaced in the online learning environment without necessary assistive technologies" (however, see also Banerjee, 2020).

\section{Student Engagement}

Student engagement is a complex and broad concept. Kahu (2013) distinguishes between the behavioral perspective of student engagement, that includes institutional policies, practices and student behaviors, the psychological perspective that encompasses behavioral, emotional and cognitive dimensions (e.g., Dogan, 2014; Gunuc \& Kuzu, 2015; Hart et al., 2011; Wang et al., 2014; Zhoc et al., 2019), the socio-cultural and the holistic perspective. Kuh views engagement as "the time and energy students devote to educationally sound activities inside and outside the classroom" (2003, p. 25), "... that contribute directly to desired outcomes" (Hu \& Kuh, 2002, p. 555). Handelsman et al. (2005) operationalize the concept through skills, emotion, participation, and performance, while Schaufeli et al. (2002) through vigor (mental resilience, effort, persistence), dedication (strong involvement, significance, enthusiasm, inspiration, pride, challenge) and absorption (highconcentration flow state).

Student engagement has been mainly investigated in the context of traditional, F2F classes, and is linked to various positive outcomes, including enhanced academic performance (Dogan, 2015; Lei et al., 2018) and critical thinking (Carini et al., 2006). During the past decades, increasingly more classes are conducted online. According to the U.S. Department of Education, National Center for Education Statistics (2019), in fall 2018, there were almost 7 million undergraduate students enrolled in distance education courses in the US. One of the challenges that institutions and instructors face is finding ways to sustain the same level of engagement when the course is 
conducted online. Within remote learning, dimensions of student engagement have been identified, including active and cooperative learning, level of academic challenge, educational experiences, and student-faculty interaction (Kuh, 2001). According to Dixson (2015), online student engagement involves attitudes, effort, cognitive, emotional, behavioral aspects, and communication with others:

students using time and energy to learn materials and skills, demonstrating that learning, interacting in a meaningful way with others in the class (enough so that those people become "real"), and becoming at least somewhat emotionally involved with their learning (i.e., getting excited about an idea, enjoying the learning and/or interaction). (p. 4)

The Online Student Engagement (OSE) scale (Dixson, 2010) measures student behaviors, feelings and connections with material and people (peers and instructor). Research findings suggest that, in online learning, student engagement is of fundamental importance for undergraduates' education and achievement (Dixson, 2015). However, online learning can have a negative impact on student engagement due to lack of interaction with instructors and other students, technical problems, students' poor time management skills and problems with instructional material (Ilgaz \& Gülbahar, 2015). Moreover, it has been argued that online engagement is correlated with academic emotions and it mediates the relationship between students' emotions and their academic achievement (Pekrun \& Linnenbrink-Garcia, 2012). Online learning might be stressful for undergraduates, particularly for students with lower academic self-efficacy (Heo \& Han, 2018), which refers to beliefs in their ability to successfully carry out academic tasks, overcome challenges and learn course material (Bandura, 1997; Schunk \& Ertmer, 2020). Student participation and synchronous engagement in online courses is related to academic performance (Duncan et al., 2012). Not much is known about online student engagement during a pandemic, when courses transitioned abruptly, mid-semester, to online mode. Technical Difficulties

Online learning students largely depend on the use of computer software and technology to attend classes and maintain their initial levels of engagement (Daniel, 2020). Remote learning raises time and space limitations, but also poses some difficulties, partly due to connectivity issues, applications lagging and computers running slowly, which may interfere with the learning process. Sitzmann et al. (2010) focused on knowledge acquisition during online instruction and tested the effects of technical difficulties on learning. The study found that, when trainees encountered technical difficulties, test performance suffered. Research on how COVID-19 has impacted internet performance found that, because of the pandemic, the Internet experienced a persistently increased load and that use of video conferencing applications has massively increased (Bergman \& Lyengar, 2020; Koeze \& Popper, 2020; Pratama et al., 2020). Chhetri (2020) conducted a mixed methods study within IT online courses, providing evidence from student's own perceptions of remote learning and found that students were challenged by technical difficulties in online classes. The current paper extends this study by including other study majors. Demuyakor (2020) studied the levels of satisfaction of international students with remote learning and observed that undergraduates living in dorms reported slow connectivity. Moreover, a qualitative study conducted by Banna et al. (2015) suggested that students who faced technical difficulties such as hardware, software and connectivity issues reported difficulty to actively engage in remote learning sessions, thus, suggesting that technical difficulties hindered students' learning and participation. Considering the fact that Banna et al. (2015) conducted their study 
before an ongoing social, economic and health crisis and fewer universities operated fully online, the current study aims to further examine how technical difficulties might be related to online engagement.

\section{Computer Self-Efficacy}

Besides technical difficulties, that are external factors interfering with online learning, students' perceived computer self-efficacy is also important to investigate in the current context. Computer self-efficacy refers to an individual's belief in their capacity to execute a wide range of computer-related tasks. Pellas (2014) and Chen (2017) found that computer self-efficacy was positively associated with student's emotional, cognitive and overall engagement. Wolverton et al. (2020) found that students' engagement is determined by their perception of their computer self-efficacy, thus, students who identify themselves as being able to expertly use digital technologies, are more likely to be engaged within an online environment. Moreover, Howard et al. (2016), suggested that students' low certainty in performing computer-related tasks is likely to have an effect on engagement.

\section{Home Distractions}

Technology is not the only bump on the road of distance learning. Divided attention disrupts learning, and there are distinct distractions when learning occurs remotely from home. This non-classroom environment, where students are indoors with family, flat mates, pets, constant access to cellphones and social media is not ideal for learning. Blasiman et al. (2018) examined six types of distractions while students watched a 5-min online lecture, from playing a video games to texting, and found significant impairment of encoding information and, in turn, performance. In fact, post-test scores of the study showed a $15 \%$ to $30 \%$ decrease - a percentage that could drop a grade as much as one to three letter grades. Student perceptions of how well they learned information from the lecture matched their actual performance, except when they underestimated the disruption that a high arousal video brought about.

Scholars have begun exploring remote learning-related home distractions during the COVID-19 pandemic. Chhetri (2020) suggested that home distractions impacted students' active engagement. Considering that COVID-19 is a recent, crucial topic and that there is not much empirical literature on it, further research is important to acquire more knowledge about how home distractions relate to online engagement. Purpose of the Present Study

In the current study, the research objective was to further investigate experiences of students whose courses abruptly transitioned from F2F or hybrid to synchronous online during to the second wave of the COVID-19 pandemic, during the Fall 2020 semester in a private, American college in Greece. The focus was on student engagement, technical difficulties, computer self-efficacy and home distractions in synchronous online instruction.

Hypothesis 1: student engagement would be negatively correlated with technical difficulties (Banna et al., 2015; Chhetri, 2020).

Hypothesis 2: student engagement would be negatively correlated with home distractions (Chhetri, 2020).

Research question: Although scholars have examined the direct effects of computer self-efficacy on student engagement (Chen, 2017; Howard et al., 2016; Pellas, 2014; Wolverton et al., 2020), to the best of our knowledge, prior research has not explored whether computer self-efficacy has an effect on the strength of the relationship between technical difficulties and online student engagement - especially during this time that working with computers is a global requirement. Due to insufficient ground 
to form a hypothesis, we investigated whether computer self-efficacy would mediate the relationship between student engagement and technical difficulties.

\section{Method}

Sample

The sample consisted of 78 participants, 53 (67.9\%) female and 25 (32.1\%) male undergraduate students of a small private American college in Greece, where, in fall 2020, classes were offered either hybrid or F2F, and very few online, and all were transitioned mid-semester to online synchronous. The students were recruited online through convenience and voluntary sampling. Ages ranged from 18 to $48(M=21.62$, $S D=4.5)$, average GPA was $3.39(S D=0.40)$ - one student did not report a GPA because they were in their first semester. Forty-one majored in psychology $(52.6 \%)$, $12(15.4 \%)$ in management and business, 8 (10.3\%) in marketing and $22 \%$ in other majors. Moreover, 6 (7.7\%) were freshmen, 28 (35.9\%) sophomores, 34 (43.6\%) juniors and $10(12.8 \%)$ seniors. Students had been enrolled in two to five courses $(M$ $=3.94, S D=0.83)$ and were living with none (alone) to six people at home $(M=$ 2.96, $S D=1.35), 97 \%$ lived with at least one more person. Two respondents reported an extreme number of people living at home and were excluded from this question analysis. The majority connected to online classes through a computer with a webcam (57.7\%), and seven (8.97\%) had been diagnosed with a learning disability (for details, see Table 1).

\section{Table 1}

Demographic Characteristics of Sample

\begin{tabular}{lcccc}
\hline \multicolumn{1}{c}{ Sample characteristic } & $n$ & $\%$ & $M$ & $S D$ \\
\hline Age $^{*}$ & & & 21.62 & 4.5 \\
Gender & & & & \\
$\quad$ Females & 53 & $67.9 \%$ & & \\
$\quad$ Males & 25 & $32.1 \%$ & & \\
Major* & & & & \\
$\quad$ Psychology & 41 & $52.6 \%$ & & \\
$\quad$ Management/Business & 12 & $15.4 \%$ & & \\
$\quad$ Marketing & 8 & $10.3 \%$ & & \\
$\quad$ Communication & 6 & $7.7 \%$ & & \\
Informational Technology & 4 & $5.1 \%$ & & \\
$\quad$ Biomedical Sciences & 2 & $2.6 \%$ & & \\
$\quad$ Graphic Design & 1 & $1.3 \%$ & & \\
Math / Physics & 1 & $1.3 \%$ & & \\
Sociology & 1 & $1.3 \%$ & & \\
Theatre Arts & 1 & $1.3 \%$ & & \\
Undecided & 1 & $1.3 \%$ & 3.94 & \\
Number of courses enrolled in & & & \\
2 & 1 & $1.3 \%$ & & \\
3 & 26 & $33.3 \%$ & & \\
4 & 28 & $35.9 \%$ & & \\
5 & 23 & $29.5 \%$ & 2.96 & \\
No. of people living with & & & & \\
participant & & & \\
0 & & $2.6 \%$ & & \\
1 & 12 & $15.8 \%$ & & \\
2 & 9 & $11.8 \%$ & &
\end{tabular}




\begin{tabular}{lcc}
3 & 27 & $35.5 \%$ \\
4 & 19 & $25.0 \%$ \\
5 & 4 & $5.3 \%$ \\
6 & 3 & $3.9 \%$ \\
Usual connection to online & \\
class* & \\
Desktop/Laptop with camera & 45 & $57.7 \%$ \\
Desktop/Laptop w/o camera & 28 & $35.9 \%$ \\
Smartphone & 3 & $3.8 \%$ \\
Tablet & 2 & $2.6 \%$ \\
Learning disabilities ${ }^{*}$ & & \\
Dyslexia & 1 & $1.3 \%$ \\
ADHD & 5 & $6.4 \%$ \\
Other & 1 & $1.3 \%$ \\
No & 71 & $91 \%$ \\
\hline
\end{tabular}

Note. ${ }^{*} N=78 .{ }^{* *} N=76$

\section{Instruments}

The demographics section consisted of 9 questions including age, gender, cumulative index (GPA), major, year of study, number of courses currently enrolled in, way of connection to online classes, and perceived reliability of students' internet connection (see Appendix A). Participants were also asked whether they live alone, and if not, specify how many people live with them from different categories including mother, father, brother, sister, grandparent, friend, flat mate, romantic partner and other (Adams \& Wu, 2003). Additionally, even though the topic of the study was not learning disabilities, we added a question asking whether participants have been diagnosed with one, for exploratory reasons.

Student engagement was measured using Dixon's (2015) online student engagement scale (OSE) consisting of 19 items (see Appendix B). A sample question is the statement "Having fun in online chats, discussions or via email with the instructor or other students". Using a 5-point Likert scale ranging from 1 (Not at all characteristic of me) to 5 (Very characteristic of me), participants rated how well each statement describes them. Higher scores indicate high student engagement levels. Analysis of the items in the scale revealed strong reliability $(\alpha=.91)$ and significant association with global engagement element $(r=.67 ; p<.001)$. Technical difficulties were measured with four statements (see Appendix $C$ ) that were generated based on Banna's et al. (2015) qualitative results. A sample question of the scale is the statement "My computer crashing". Using a 7-point scale, participants were asked to rate how frequently they experience each of the issues. Response options ranged from 1 (Never) to 7 (Always). Higher scores indicate a higher level of technical difficulties.

Home distractions were measured with three statements created based on Chhetri's (2020) qualitative study (see Appendix D). Using a 7-point scale ranging from 1 (Never) to 7 (Always), participants indicated the frequency with which they had experienced each of the distractions during an online class, assignments or studying. A sample question was "My surroundings at home distract me (TV, pets, loud noises)". Higher scores indicate more home distractions.

Computer self-efficacy was measured with Dang's et al. (2016) computer selfefficacy scale (see Appendix E), consisting of three items. Dang et al. (2016) condensed the measures of student characteristics and efficacy from Selim (2007) 
and Law et al. (2010). The scale included statements such as "In general, I am comfortable with using computers and software applications". Using a 7-point Likert scale, ranging from 1 (Strongly Disagree) to 7 (Strongly Agree), participants were instructed to respond to each statement. Higher scores indicate increased perception for participants' own ability to apply their computer skills to a wider range of computer-related tasks. Analysis of the items in the scale revealed strong reliability $(\alpha=.912)$.

Considering the limited knowledge regarding online student engagement during a pandemic, we decided to include two open-ended questions that would allow students to describe their own experience with the online learning environment (see Appendix F). Specifically, participants were asked to write aspects in online classes that they found (a) challenging and (b) enjoyable.

Procedure

The current study was approved by the Ad-hoc ethics committee ${ }^{1}$. Data were collected online through the use of the Google Forms

(https://docs.google.com/forms/u/0/) which remained open to accept participations for a total of 13 days (November $22^{\text {nd }}$ to December $4^{\text {th }}, 2020$ ), after all courses had shifted to online. The survey was distributed to undergraduate students in numerous courses and on social media used by students in this college, therefore the response rate could not be calculated.

The first page of the survey provided the informed consent form that stated the expected duration, anonymity and participant rights. It was suggested that they complete the survey in one go, alone, in a silent environment so as to avoid environmental factors that could possibly disrupt the participant while completing the study and thus interfere with the results. Once participants gave their consent, they proceeded to the questionnaire and, upon completion, were debriefed. They did not receive credit or monetary award.

\section{Results}

Means and standard deviations for online student engagement, technical difficulties, home distractions and computer self-efficacy can be seen in Table 2, and their correlations in Table 3.

\section{Table 2}

Means and Standard Deviations for Online Student Engagement, Technical Difficulties, Home Distractions and Computer Self-Efficacy

\begin{tabular}{lcc}
\multicolumn{1}{c}{ Variable } & $M$ & $S D$ \\
\hline Online student engagement & 3.28 & 0.99 \\
Making sure to study on a regular basis & 3.32 & 1.21 \\
Putting forth effort & 3.77 & 1.04 \\
$\quad \begin{array}{l}\text { Staying up on the readings } \\
\text { Looking over class notes between getting online to make }\end{array}$ & 3.22 & 1.25 \\
$\quad$ sure I & & \\
$\quad$ understand the material & 2.83 & 1.29 \\
Being organized & & \\
$\quad \begin{array}{l}\text { Taking good notes over readings, PowerPoints, or video } \\
\text { lectures }\end{array}$ & 3.56 & 1.31 \\
Listening/reading carefully & 3.33 & 1.52 \\
\end{tabular}

\footnotetext{
${ }^{1}$ examines applications for undergraduate research to ensure that ethical procedures are followed and quality of research is maintained at desired standards
} 
Finding ways to make the course material relevant to my life

Applying course material to my life

Finding ways to make the course interesting to me

Really desiring to learn the material

Having fun in online chats, discussions or via email with the instructor or other students

Participating actively in small-group discussion forums

Helping fellow students

Getting a good grade

Doing well on the exams/assessments

Engaging in conversations online (chat, discussions, email)

Posting in the discussion forum / MS Teams chat regularly

Getting to know other students in the class

Technical difficulties

2.72

Slow computer

Computer crashing

Lose internet connection

Slow internet

Home distractions

People living together

Cell phone / Social media

TV / pets / noise

Computer self-efficacy

Enjoy using computers

5.14

Confident - computers

Comfortable - computers / software apps

5.16

Note. $N=78$

5.30

\section{Table 3}

Correlations for Online Student Engagement, Technical Difficulties, Home Distractions and Computer Self-Efficacy

\begin{tabular}{lcccc}
\multicolumn{1}{c}{ Variable } & 1 & 2 & 3 & 4 \\
\hline 1. Online student & - & $-.557^{\star \star}$ & $-.646^{\star \star}$ & $.576^{* \star}$ \\
engagement & & - & & \\
2. Technical difficulties & & & $.562^{* \star}$ & $-.557^{\star \star}$ \\
3. Home distractions & & - & $-.410^{\star *}$ \\
4. Computer self-efficacy & & & - \\
\hline Note. $N=78 .{ }^{* *} p<.01$ & & &
\end{tabular}

The overall student engagement score ranged from 1.37 to $5.00(M=3.28, S D=$ $0.99)$. There was a significant difference between females $(M=3.50, S D=0.74)$ and males $(M=2.82, S D=1.27),[t(31.9)=2.48, p<.05$, two-tailed, Cohen's $d=.722)]$ There was no significant difference between different years of study in student engagement scores, $F(3,74)=2.30, p>.05$.

The relationship between technical difficulties $(M=3.59, S D=1.49)$ and online student engagement $(M=3.28, S D=0.99)$ was investigated with the use of the Pearson correlation coefficient. The analysis supported the first hypothesis and 
revealed a significant large negative relationship; $r(78)=-.557, p<.001$, with higher technical difficulties associated with lower student engagement scores. This relationship was contingent on computer self-efficacy. There was a moderate, negative, partial correlation between technical difficulties and student engagement, when controlling for computer self-efficacy, $r(78)=-.349, p<.05$. An inspection of the zero-order correlation ( $r=-.557$ ) suggested that computer self-efficacy weakened the strength of the relationship between these two variables. Computer self-efficacy $(M=5.14, S D=1.76)$ was positively correlated with student engagement, $r(78)=.576, p<.001$ and negatively with reported technical difficulties, $r(78)=-.557, p<.001$.

The second hypothesis was also supported. There was a significant large negative relationship between home distractions $(M=4.24, S D=1.69)$ and student engagement $(M=3.28, S D=0.99) ; r(78)=-.646, p<.001$, with higher home distractions scores associated with lower student engagement. The number of people living at home $(M=2.96, S D=1.35)$ was not correlated to student engagement, $r(76)=-.167, p>.05$, nor to the statement Family members or other people living with me (roommate, friend, romantic partner) distract me from classes / assignments / studying / exams, $(M=3.68, S D=1.93), r(76)=-.015, p>.05$, indicating that the disruptions occurred irrespective of the number of people students lived with. Indeed, standard multiple regression was carried out to assess the ability of the three types of distractions to predict online student engagement. The results indicated that the model explained $43.4 \%$ of the variance and was a significant predictor of online student engagement, $F(3,74)=18.88, p<.001, f^{2}=0.77$. Cellphone use (social media, applications) $(B=-.385, p<.001)$ was the distraction that contributed significantly to the model.

A sensitivity analysis conducted using $\mathrm{G}^{*}$ Power (Faul et al., 2007) indicated that given a total sample size of 78 , the required effect sizes to detect a power of 0.80 at $a=.05$ are: $r=.311$ for Pearson correlations; Cohen's $d=0.688$ for independent samples t-test for gender; $f^{2}=0.08$ for multiple regression with three predictors. All analyses exceeded the minimum effect sizes required.

In terms of the perceived challenges in online classes, 74 participants (94.9\%) reported facing at least one $(M=1.18)$. Open ended questions were collected, coded and grouped into thematic categories (see Table 4). The most commonly mentioned challenge, reported by 34 students (43.6\%) was difficulty to focus mainly due to home distractions such as cell phones and social media, thus supporting the quantitative results, but also long exposure to a computer screen. Out of the seven students diagnosed with a learning disability, three reported difficulty to concentrate. There was no difference in student engagement between those who reported decreased focus $(n=34)$ and those who did not $(n=44)[t(76)=-0.56, p<.05$, twotailed)]. Moreover, 16 participants (20.5\%) found technical difficulties to be an issue, especially their internet connection, and to a lesser extent hardware or the teleconference platform, as they hindered their focus and could not follow the class flow seamlessly. Fifteen (19.2\%) reported impoverished socialization and interaction with instructors and classmates. Four students $(5.1 \%)$ mentioned that they do not find anything challenging, and two (2.6\%), one of whom diagnosed with ADHD, that everything is challenging.

\section{Table 4 \\ Online Course Challenges, Frequency Distributions, Percentages and Example Quotes}




\begin{tabular}{|c|c|c|c|}
\hline Dimension & $n$ & $\%$ & Example quote \\
\hline Reported at least one challenge & 74 & $94.9 \%$ & \\
\hline $\begin{array}{l}\text { Attention / focus / distractions } \\
\text { total }\end{array}$ & 34 & $43.6 \%$ & \\
\hline Attention / focus (general) & 22 & $28.2 \%$ & $\begin{array}{l}\text { "Being concentrated all }[\ldots] \text { the time" } \\
\text { (Female, Shipping Management) }\end{array}$ \\
\hline Home distractions, cell phone & 13 & $16.7 \%$ & $\begin{array}{l}\text { "Avoiding distractions such as cell } \\
\text { phones" (Female, Sociology) }\end{array}$ \\
\hline Too many hours on screen & 3 & $3.8 \%$ & $\begin{array}{l}\text { "I struggle to pay attention because } \\
\text { my eyes get so tired from staring at } \\
\text { my laptop screen for many hours." } \\
\text { (Female, Psychology) }\end{array}$ \\
\hline $\begin{array}{l}\text { Low concentration when few } \\
\text { visuals are used }\end{array}$ & 1 & $1.3 \%$ & $\begin{array}{l}\text { "Paying attention when there are not } \\
\text { many visuals in in the lecture" } \\
\text { (Female, Psychology) }\end{array}$ \\
\hline $\begin{array}{l}\text { Internet connection / technical } \\
\text { difficulties total }\end{array}$ & 16 & $20.5 \%$ & \\
\hline Internet connection & 15 & $19.2 \%$ & $\begin{array}{l}\text { "Internet connection is sometimes } \\
\text { slow, and we cannot hear the } \\
\text { teacher" (Female, Psychology) }\end{array}$ \\
\hline Technical difficulties & 3 & $3.8 \%$ & $\begin{array}{l}\text { "[communication platform] throwing } \\
\text { me out" (Male, Marketing) }\end{array}$ \\
\hline $\begin{array}{l}\text { Interaction / socializing / } \\
\text { personal contact }\end{array}$ & 15 & $19.2 \%$ & $\begin{array}{l}\text { "The lack of feeling connected with } \\
\text { professor and/or classmates" (Male, } \\
\text { International Relations and } \\
\text { European Affairs) } \\
\text { "[cannot] ask the small questions } \\
\text { one usually asks at the end of the } \\
\text { class in private" (Female, } \\
\text { Psychology) }\end{array}$ \\
\hline Keeping up with material & 6 & $7.7 \%$ & $\begin{array}{l}\text { "following the course material and } \\
\text { thoroughly understanding" (Female, } \\
\text { Psychology) }\end{array}$ \\
\hline In-class participation & 6 & $7.7 \%$ & $\begin{array}{l}\text { "It's difficult to participate" (Female, } \\
\text { Psychology) }\end{array}$ \\
\hline Low motivation & 4 & $5.1 \%$ & $\begin{array}{l}\text { "I find myself having a lack of } \\
\text { motivation when the course is } \\
\text { online" (Female, Psychology) }\end{array}$ \\
\hline Online exams & 1 & $1.3 \%$ & $\begin{array}{l}\text { "the online exams" (Female, } \\
\text { Psychology) }\end{array}$ \\
\hline Everything & 2 & $2.6 \%$ & \\
\hline Nothing & 4 & $5.1 \%$ & \\
\hline
\end{tabular}

Note. $N=78$ (each participant who reported at least one challenge provided 1.18 responses on average)

When participants were asked to name the aspects they enjoy in online courses, 76 $(97.4 \%)$ mentioned at least one $(M=1.05)$. Time efficiency was reported by 31 students $(39.7 \%)$, mainly related to absence of commuting to the college $(n=22$, $28.2 \%$ ) and having more free time in-between classes. Convenience was reported 
by $29(37.2 \%)$ students, mainly attending class from the comfort of their home (for more details, see Table 5). There was no difference in student engagement between those who reported time efficiency and those who did not $[t(76)=2.2, p<.05$, twotailed)], nor between students mentioning home comfort and those who did not $[t$ $(76)=-0.49, p<.05$, two-tailed)]. Several students enjoyed the fact that they could engage in non-academic activities during class when the webcam and microphone were off; their average GPA was $2.98(S D=0.56)$, compared to $3.43(S D=0.36)$ of those who did not mention such "multitasking". Finally, some mentioned that it is very convenient when lectures are recorded, all of whom scored above average in home distractions.

\section{Table 5}

Online Course Enjoyment, Frequency Distributions, Percentages and Example Quotes

\begin{tabular}{|c|c|c|c|}
\hline Dimension & $n$ & $\%$ & Example quote \\
\hline $\begin{array}{l}\text { Reported at least one aspect they } \\
\text { enjoy }\end{array}$ & 76 & $97.4 \%$ & \\
\hline Time efficiency /convenience total & 31 & $39.7 \%$ & \\
\hline No commuting & 22 & $28.2 \%$ & $\begin{array}{l}\text { "Not having to go to [college] I } \\
\text { live far, and it takes a lot of } \\
\text { time for me" (Male, } \\
\text { Psychology) }\end{array}$ \\
\hline More free time / rest & 10 & $12.8 \%$ & $\begin{array}{l}\text { "Getting more hours of sleep" } \\
\text { (Male, Marketing) }\end{array}$ \\
\hline More time to study & 2 & $2.6 \%$ & $\begin{array}{l}\text { "Not wasting time [...] and } \\
\text { having more time to study." } \\
\text { (Female, Psychology) }\end{array}$ \\
\hline Home comfort & 29 & $37.2 \%$ & $\begin{array}{l}\text { "Wearing pj's and having a } \\
\text { blanket around me" (Female, } \\
\text { Marketing) }\end{array}$ \\
\hline $\begin{array}{l}\text { Engage in non-academic activities } \\
\text { during class }\end{array}$ & 8 & $10.3 \%$ & $\begin{array}{l}\text { "I am relatively free to do what } \\
\text { I want during a lecture." (Male, } \\
\text { Psychology) }\end{array}$ \\
\hline $\begin{array}{l}\text { Not distracted / stressed by others in } \\
\text { the classroom }\end{array}$ & 4 & $5.1 \%$ & $\begin{array}{l}\text { "I feel more confident when I } \\
\text { have to talk, because I am not } \\
\text { surrounded by other people, } \\
\text { something that makes me } \\
\text { anxious sometimes" (Female, } \\
\text { Psychology) }\end{array}$ \\
\hline Recorded lectures & 3 & $3.8 \%$ & $\begin{array}{l}\text { "It can be recorded (with the } \\
\text { permission of the professor } \\
\text { and the other students) and be } \\
\text { watched later" (Female, } \\
\text { Math/Physics) }\end{array}$ \\
\hline $\begin{array}{l}\text { Online communication with instructor } \\
\text { and students }\end{array}$ & 1 & $1.3 \%$ & $\begin{array}{l}\text { "The contact with fellow } \\
\text { students and professors" } \\
\text { (Female, Psychology) }\end{array}$ \\
\hline Audio-visual material & 1 & $1.3 \%$ & $\begin{array}{l}\text { "Audio-visual material that is } \\
\text { used synchronously with the } \\
\text { lecture" (Male, Psychology) }\end{array}$ \\
\hline
\end{tabular}


Note. $N=78$ (each participant who reported at least one challenge provided 1.05 responses on average)

\section{Discussion}

The current study aimed to extend literature regarding online student engagement in the context of the COVID-19 pandemic, exploring technical difficulties, home distractions and computer self-efficacy. The first hypothesis that student engagement would be negatively correlated with technical difficulties was supported and complemented by the open-ended question analysis. These findings are in line with Banna el al. (2015) and Sitzmann et al. (2010) who found that such difficulties, including unreliable connectivity, were associated with lower student engagement, as they interfere with learning and participation. The problem is intensified during the pandemic, as there is a global over-reliance on remote collaboration applications (Bergman \& Lyengar, 2020; Koeze \& Popper, 2020). Chhetri (2020) also found that students mention technical difficulties as a challenge in online classes. There is a need for a contingency plan to mitigate unexpected technical issues of online education platforms (Bao, 2020), so that students can reap the benefits of technology in a way that leads them to engage with content, peers and instructors (Klasen et al., 2020).

The relationship between student engagement and technical difficulties was mediated by computer self-efficacy. Thus, students who were not confident in their computer skills and encountered technical difficulties had lower engagement scores than those with higher computer self-efficacy facing a similar situation. Similar to Pellas (2014) and Chen (2017), we found that computer self-efficacy was associated with student engagement in online synchronous learning. Results also support Wolverton et al. (2020) and Howard et al. (2016) findings, as it was demonstrated that students who identify themselves as being able to expertly use digital technologies are more likely to be engaged within an online environment. It is recommended that students receive support to familiarize themselves with computers and e-learning systems, become more confident with computers and overcome technical difficulties more easily (Alqahtani \& Rajkhan, 2020; Banna et al., 2015; Chhetri, 2020). Future studies can examine computer self-efficacy and online student engagement pre- and post- technical support training. We also found that students who had higher scores of computer self-efficacy reported less frequent technical difficulties. It may be the case that due to confidence in their computer skills, they perceived or recalled less such difficulties.

The second hypothesis was also supported. Students who faced more frequent home distractions, especially from cell phones or social media, had lower student engagement scores. The number of cohabitants was not related to the amount of distraction experienced because of them. Experimental evidence (Blasiman et al., 2018) has indicated impaired learning when attention is divided, and Chhetri (2020) found that distractions are one of the challenges mentioned by online learners during COVID-19. The findings are complemented by the open-ended questions, where students mentioned difficulty to concentrate due to cellphones, social media and allday screen time, irrespective of a learning disability diagnosis.

When asked what they enjoy most in distance learning, in line with Chhetri (2020), students reported flexibility and that they have more time to relax or study due to lack of commuting. Convenience and home comfort were also a very important element they enjoyed, and it is interesting to note that this was the very aspect that interfered with their concentration and engagement; it seems that remote learning from home is 
a double-sided coin. Future studies could investigate which student, instructor and course characteristics might determine which side the coin will land on.

Impoverished interaction with instructors and peers, a key component of promoting learning (Bernard et al. 2009; Conrad \& Donaldson, 2004) and student engagement (Dixson, 2015; Kuh, 2001), was another problematic aspect reported by students, similarly to Chhetri (2020). Indeed, a sense of community is an important factor impacting student engagement (Farrell \& Brunton, 2020). Dixson (2010) reported a strong correlation between student engagement and student- and instructor-student communication. There is a negative impact on online student engagement due to lack of such interaction (Ilgaz \& Gülbahar, 2015), while active learning enhances engagement (Venton \& Pompano, 2021). It is evident that incorporating activities to enhance live interaction in online classes can subdue feelings of isolation and lack of closeness with peers and instructors.

Aligned with Chhetri (2020), some of our participants mentioned that they prefer it when lectures are recorded, so that they can go over them again. McBrien et al. (2009) suggested that lectures can be recorded so that instructors can assess participation and interaction. This would also help students who face technical difficulties or distractions and hence cannot connect or properly focus during the synchronous lecture, not fall back on material. However, GDPR issues must be considered and consent must be granted from the educational institution, instructor and students.

As little research exists on online student engagement during the COVID-19 pandemic, especially in relation to home distractions and technology issues, this study attempted to enrich literature on possible difficulties students face in remote learning. Given the uncertainty regarding how long the lockdown will continue for, this study could be of value to help improve possible shortcomings in online classes. It would be interesting to extend the current findings in vocational distance education.

This study is not without limitations. Causality among variables cannot be assumed. Furthermore, the sample consisted of undergraduate students only from one college in Greece, and more than half were females or psychology majors. In addition, participants were not asked whether at the beginning of the semester they had opted for F2F, hybrid or online courses, so it remains unknown how many shifted midsemester to online. It is possible that students with higher computer self-efficacy had selected an online course to begin with. However, in the specific college, very few courses were delivered online from the onset of the semester. Future studies can examine the relationship among different delivery modes with student engagement, technical difficulties, home distractions and computer self-efficacy.

Conclusion and Suggestions

Following the mid-semester online transition due to COVID-19, this study investigated online learning related behaviors. Evidently, this change in environment, from a traditional, F2F or hybrid classroom to a home setting, comes with unique challenges to students. It was demonstrated that student engagement is associated with technical difficulties, home distractions, and computer self-efficacy. All things considered, this study can provide some insights to understand possible problems students might encounter remotely and to make adjustments to ensure that those students are provided with the necessary assistance moving forward. Under the circumstances of COVID-19, there is uncertainty regarding how long universities will continue to operate fully online. Possibly after the pandemic, online classes will 
eventually become an integral component of more higher education institutions, in which case our results point to the following suggestions:

- Institution

- Offer technical training and support to students who need it, to familiarize themselves / become more confident with computers and elearning systems, and overcome technical difficulties more easily, so that they can reap the benefits of technology in a way that leads them to engage with content, peers and instructors.

- Students

- Students should refrain from using cellphones and social media during class and study time, as our results confirmed common knowledge: cellphone use (social media, applications) was the best predictor of online student engagement, among home distractions.

- Students should take regular breaks from long exposure to the computer screen, as it impairs their ability to focus.

- Instructors

- Incorporate activities to enhance live interaction in online classes can subdue feelings of isolation and lack of closeness with peers and instructors.

- Record lectures so that students can go over them again, especially those who face technical difficulties or distractions and hence cannot connect or properly focus during the synchronous lecture (GDPR issues must be considered).

\section{References}

Adams, R. \& Wu, M. (eds.) (2003). Programme for International Student Assessment (PISA): PISA 2000 Technical Report, PISA, OECD Publishing, Paris, https://doi.org/10.1787/9789264199521-en.

Adnan, M., \& Anwar, K. (2020). Online learning amid the COVID-19 pandemic: Students' perspectives. Journal of Pedagogical Sociology and Psychology, 2(1), 45-51. https://doi.org/10.33902/JPSP.2020261309

Alqahtani, A., Y. \& Rajkhan, A., A. (2020). E-Learning critical success factors during the COVID-19 pandemic: A comprehensive analysis of E-Learning managerial perspectives. Education Sciences, 10(9), 216. https://doi.org/10.3390/educsci10090216

Azzi-Huck, K. \& Shmis, T. (2020, March 18). Managing the impact of COVID-19 on education systems around the world: How countries are preparing, coping, and planning for recovery. https://blogs.worldbank.org/education/managingimpact-covid-19-education-systems-around-world-how-countries-arepreparing

Bandura A. (1997). Self-efficacy: The exercise of control. Worth Publisher.

Banna, J. C., Stewart, M., Lin, G., \& Fialkowski, M. K. (2015). Interaction matters: Strategies to promote engaged learning in an online introductory nutrition course. Journal of Online Learning and Teaching, 11(2), 249-261. 
Bao, W. (2020). COVID-19 and online teaching in higher education: A case study of Peking University. Human Behavior and Emerging Technologies. https://doi.org/10.1002/hbe2.191

Barnard-Brak, L., \& Sulak, T. (2010). Online versus face-to-face accommodations among college students with disabilities. The Amer. Jrnl. of Distance Education, 24(2), 81-91. https://doi.org/10.1080/08923641003604251

Bergman, A., Lyengar, J. (2020, April 8). How COVID-19 is affecting internet performance. https://www.fastly.com/blog/how-covid-19-is-affecting-internetperformance

Bernard, R. M., Abrami, P. C., Borokhovski, E., Wade, C. A, Tamim, R. M., Surkes, M. A., Bethel, E. C. (2009). A meta-analysis of three types of interaction treatments in distance education. Review of Educational Research, 79(3), 1243-1289. https://doi.org/10.3102/0034654309333844

Blasiman, R. N., Larabee, D., \& Fabry, D. (2018). Distracted students: A comparison of multiple types of distractions on learning in online lectures. Scholarship of Teaching and Learning in Psychology, 4(4), 222-230. https://doi.org/10.1037/stl0000122

Burghstahler, S. (2003). Web-based distance learning and the second digital divide. In M. Hricko (Eds.), Design and Implementation of Web-Enabled Teaching Tools (pp. 83-97). IGI Global. https://doi.org/10.4018/978-1-59140-1070. ch005

Cao, W., Fang, Z., Hou, G., Han, M., Xu, X., Dong, J., \& Zheng, J. (2020). The psychological impact of the COVID-19 epidemic on college students in China. Psychiatry Research, 287, 112934. https://doi.org/10.1016/j.psychres.2020.112934

Carini, R. M., Kuh, G. D., \& Klein, S. P. (2006). Student engagement and student learning: Testing the linkages. Research in Higher Education, 47(1), 1-32. https://doi.org/10.1007/s11162-005-8150-9

Chen, I. S. (2017). Computer self-efficacy, learning performance, and the mediating role of learning engagement. Computers in Human Behavior, 72, 362-370 https://doi.org/10.1016/j.chb.2017.02.059

Chhetri, C. (2020, October). "I Lost Track of Things" Student Experiences of Remote Learning in the Covid-19 Pandemic. In Proceedings of the 21st Annual Conference on Information Technology Education (pp. 314-319). https://doi.org/10.1145/3368308.3415413

Conrad, R. \& Donaldson, J. (2004). Engaging the online learner: Activities and resources for creative instruction. San Francisco, California: John Wiley \& Sons.

Cucinotta, D., \& Vanelli, M. (2020). WHO declares covid-19 a pandemic. Acta BioMedica: Atenei Parmensis, 91(1), 157-160. https://doi.org/10.23750/abm.v91i1.9397

Dang, Y., Zhang, Y., Ravindran, S., \& Osmonbekov, T. (2016). Examining student satisfaction and gender differences in technology-supported, blended Learning. Journal of Information Systems Education, 27(2), 119-130.

Daniel, S. J. (2020). Education and the COVID-19 pandemic. Prospects, 1-6. https://doi.org/10.1007/s11125-020-09464-3

Debbarma, I., \& Durai, T. (2021). Educational disruption: Impact of COVID-19 on students from the Northeast states of India. Children and youth services review, 120, 105769. https://doi.org/10.1016/j.childyouth.2020.105769 
Demuyakor, J. (2020). Coronavirus (COVID-19) and online learning in higher institutions of education: A survey of the perceptions of Ghanaian international students in China. Online Journal of Communication and Media Technologies, 10(3). https://doi.org/10.29333/ojcmt/8286

Dhawan, S. (2020). Online learning: A panacea in the time of COVID-19 crisis. Journal of Educational Technology Systems, 49(1), 5-

22. https://doi: $10.1177 / 0047239520934018$

Dixson, M. D. (2010). Creating effective student engagement in online courses: What do students find engaging? Journal of the Scholarship of Teaching and Learning, 10(2), 1 - 13

Dixson, M. D. (2015). Measuring student engagement in the online course: The Online Student Engagement Scale (OSE). Online Learning, 19(4) http://dx.doi.org/10.24059/olj.v19i4.561

Dogan, U. (2014). Validity and reliability of student engagement scale. Bartin Üniversitesi Egitim Fakültesi Dergisi, 3(2), 390-403. Doi:

10.14686/BUEFAD.201428190

Dogan, U. (2015). Student engagement, academic self-efficacy, and academic motivation as predictors of academic performance. The Anthropologist, 20(3), 553-561. https://doi.org/10.1080/09720073.2015.11891759

Duncan, K., Kenworthy, A., \& McNamara, R. (2012). The effect of synchronous and asynchronous participation on students' performance in online accounting courses. Accounting Education, 21(4), 431-449. https://doi.org/10.1080/09639284.2012.673387

Farrell, O., \& Brunton, J. (2020). A balancing act: a window into online student engagement experiences. Int J Educ Technol High Educ, 17, 1-19. https://doi.org/10.1186/s41239-020-00199-x

Faul, F., Erdfelder, E., Lang, A.-G., \& Buchner, A. (2007). G*Power 3: A flexible statistical power analysis program for the social, behavioral, and biomedical sciences. Behavior Research Methods, 39, 175-191. http://dx.doi.org/10.3758/BF03193146

Garris, C. P., \& Fleck, B. (2020). Student evaluations of transitioned-online courses during the covid-19 pandemic. Scholarship of Teaching and Learning in Psychology. https://doi.org/10.1037/stl0000229

Gazmararian, J., Weingart, R., Campbell, K., Cronin, T., \& Ashta, J. (2021). Impact of COVID-19 pandemic on the mental health of students from 2 semi-rural high schools in Georgia. Journal of School Health, 91(5), 356-369. https://doi.org/10.1111/josh.13007

Gunuc, S., \& Kuzu, A. (2015). Student engagement scale: development, reliability and validity. Assessment \& Evaluation in Higher Education, 40(4), 587-610. https://doi.org/10.1080/02602938.2014.938019

Handelsman, M. M., Briggs, W. L., Sullivan, N., \& Towler, A. (2005). A measure of college student course engagement. The Journal of Educational Research, 98(3), 184-191. https://doi-org.acg.idm.oclc.org/10.3200/JOER.98.3.184-192

Hart, S. R., Stewart, K., \& Jimerson, S. R. (2011). The Student Engagement in Schools Questionnaire (SESQ) and the Teacher Engagement Form-New (TERF-N): Examining the preliminary evidence. Contemporary School Psychology, 15, 67-79. https://doi.org/10.1007/BF03340964

Heo, J., Han, S. (2018). Effects of motivation, academic stress and age in predicting self-directed learning readiness (SDLR): Focused on online college 
students. Educ Inf Technol 23, 61-71. https://doi.org/10.1007/s10639-0179585-2

Howard, S. K., Ma, J., Yang, J. (2016). Student rules: Exploring patterns of students' computer-efficacy and engagement with digital technologies in learning.

Elsevier, 101, 29-42. https://doi.org/10.1016/j.compedu.2016.05.008

Hu, S \& Kuh, G. D. (2002) Being (dis)engaged in educationally purposeful activities: The influences of student and institutional characteristics. Research in Higher Education, 43(5), 555-575. https://doi.org/10.1023/A:1020114231387

Ilgaz, H., \& Gülbahar, Y. (2015). A snapshot of online learners: E-readiness, esatisfaction and expectations. International Review of Research in Open and Distributed Learning, 16(2), 171-187. https://doi.org/10.19173/irrodl.v16i2.2117

Kahu, E. R. (2013) Framing student engagement in higher education. Studies in Higher Education, 38(5), 758-773. https://doi.org/10.1080/03075079.2011.598505

Klasen, J.M., Meienberg, A., \& Bogie, B.J.M. (2020). Medical student engagement during COVID-19: Lessons learned and areas for improvement. Medical Education, 55, 115- 118. https://doi.org/10.1111/medu.14405

Koeze, E., Popper, N. (2020, April 7). The virus changed the way we internet. https://www.nytimes.com/interactive/2020/04/07/technology/coronavirusinternet-use.html

Kuh, G. (2001). Assessing what really matters to student learning. Change: The magazine of higher learning, 33(3), 10-17. https://doi.org/10.1080/00091380109601795

Kuh, G. D. (2003). What we're learning about student engagement from NSSE: Benchmarks for effective educational practices. Change: The Magazine of Higher Learning, 35, 24-32. https://doi.org/10.1080/00091380309604090

Law, K. M. Y., Lee, V. C. S., \& Yu, Y. T. (2010). Learning motivation in E-Learning facilitated computer programming courses. Computers \& Education, 55(1), 218-228. https://doi.org/10.1016/..compedu.2010.01.007

Lei, H., Cui, Y., \& Zhou, W. (2018). Relationships between student engagement and academic achievement: A meta-analysis. Social Behavior and Personality: An International Journal, 46(3), 517-528. https://doi.org/10.2224/sbp.7054

Marinoni, G., Van't Land, H., \& Jensen, T. (2020). The impact of Covid-19 on higher education around the world. IAU Global Survey Report.

McBrien, J. L., Cheng, R., \& Jones, P. (2009). Virtual spaces: Employing a synchronous online classroom to facilitate student engagement in online learning. The International Review of Research in Open and Distributed Learning, 10(3). https://doi.org/10.19173/irrodl.v10i3.605

Parlapani, E., Holeva, V., Voitsidis, P., Blekas, A., Gliatas, I., Porfyri, G. N., Golemis, A., Papadopoulou, K., Dimitriadou, A., Chatzigeorgiou, A. F., Bairachtari, V., Patsiala, S., Skoupra, M., Papigkioti, K., Kafetzopoulou, C., \& Diakogiannis, I. (2020). Psychological and behavioral responses to the COVID-19 pandemic in Greece. Frontiers in Psychiatry, 11. https://doi.org/10.3389/fpsyt.2020.00821

Pekrun R., Linnenbrink-Garcia L. (2012). Academic emotions and student engagement. In Christenson S., Reschly A., Wylie C. (eds) Handbook of Research on Student Engagement (pp. pp 259-282). Springer, Boston, MA . https://doi.org/10.1007/978-1-4614-2018-7 12 
Pellas, N. (2014). The influence of computer self-efficacy, metacognitive selfregulation and self-esteem on student engagement in online learning programs: Evidence from the virtual world of Second Life. Computers in Human Behavior, 35, 157-170. https://doi.org/10.1016/j.chb.2015.07.043

Pratama, H., Azman, M. N. A., Kassymova, G. K., \& Duisenbayeva, S. S. (2020). The Trend in using online meeting applications for learning during the period of pandemic COVID-19: A literature review. Journal of Innovation in Educational and Cultural Research, 1(2), 58-68. https://doi.org/10.46843/jiecr.v1i2.15

Ratcliff, J. J., Minster, K. I., \& Monheim, C. (2021). Engaging students in an online format during the COVID-19 pandemic: A jury voir dire activity. Scholarship of Teaching and Learning in Psychology. Advance online publication. https://doi.org/10.1037/stl0000246

Schaufeli, W. B., Martínez, I. M., Marques Pinto, A., Salanova, M., \& Bakker, A. B. (2002). Burnout and engagement in university students: A cross-national study. Journal of Cross-Cultural Psychology, 33(5), 464-481. https://doiorg.acg.idm.oclc.org/10.1177/0022022102033005003

Schunk D.H, \& Ertmer P.A. (2000) Self-regulation and academic learning: Selfefficacy enhancing interventions. Handbook of Self-Regulation, 631-649. Elsevier. https://doi.org/10.1016/B978-012109890-2/50048-2

Selim, H. M. (2007). Critical success factors for E-Learning acceptance: Confirmatory factor models. Computers \& Education, 49(2), 396-413. https://doi.org/10.1016/i.compedu.2005.09.004

Shahzad, A., Hassan, R., Aremu, A. Y., Hussain, A., \& Lodhi, R. N. (2020). Effects of COVID-19 in E-learning on higher education institution students: the group comparison between male and female. Quality \& Quantity, 122. https://doi.org/10.1007/s11135-020-01028-z

Siettos, C., Anastassopoulou, C., Tsiamis, C., Vrioni, G., \& Tsakris, A. (2021). A bulletin from Greece: A health system under the pressure of the second covid19 wave. Pathogens and Global Health, 1-2. https://doi.org/10.1080/20477724.2021.1881372

Simpson-Scarborough (2020, April). Higher Ed and COVID-19 national student survey. https://info.simpsonscarborough.com/april-replication-nationalstudent-survey-download.

Sintema, E. J. (2020). Effect of COVID-19 on the performance of grade 12 students: Implications for STEM education. Eurasia Journal of Mathematics, Science and Technology Education, 16(7), em1851. https://doi.org/10.29333/ejmste/7893

Sitzmann, T., Ely, K., Bell, B. S., \& Bauer, K. N. (2010). The effects of technical difficulties on learning and attrition during online training. Journal of Experimental Psychology: Applied, 16(3), 281-292. https://doiorg.acg.idm.oclc.org/10.1037/a0019968

Son, C., Hegde, S., Smith, A., Wang, X., \& Sasangohar, F. (2020). Effects of COVID-19 on college students' mental health in the United States: Interview survey study. Journal of Medical Internet Research, 22(9), e21279. https://doi.org/10.2196/21279

Steele, J. P., \& Fullagar, C. J. (2009). Facilitators and outcomes of student engagement in a college setting. The Journal of Psychology, 143(1), 5-27. https://doi.org/10.3200/JRLP.143.1.5-27 
Sweller, J. (1988). Cognitive load during problem solving: Effects on learning. Cognitive Science, 12(2), 257-285. https://doi.org/10.1207/s15516709cog1202_4

U.S. Department of Education, National Center for Education Statistics. (2019). Digest of Education Statistics. https://nces.ed.gov/fastfacts/display.asp?id=80

Venton, B.J., \& Pompano, R.R. (2021). Strategies for enhancing remote student engagement through active learning. Anal Bioanal Chem 413, 1507-1512 (2021). https://doi.org/10.1007/s00216-021-03159-0

Vinkers, C. H., Amelsvoort, T. V., Bisson, J. I., Branchi, I., Cryan, J. F., Domschke, K., Howers, O. D., Manchi, M., Pinto, L., de Quervain, D., Schmidt, M. V., Nic, J. A., \& Wee, N. J. (2020). Stress resilience during the coronavirus pandemic. European Neuropsychopharmacology, 12-16. https://doi.org/10.1016/i.euroneuro.2020.05.003

Wang, Z., Bergin, C., \& Bergin, D. A. (2014). Measuring engagement in fourth to twelfth grade classrooms: The Classroom Engagement Inventory. School Psychology Quarterly, 29(4), 517-535. https://doi.org/10.1037/spq0000050

Wang, C., \& Zhao, H. (2020). The Impact of COVID-19 on anxiety in Chinese university students. Front. Psychol. 11:1168. https://doi.org/10.3389/fpsyg.2020.01168

Wirkner, J., Christiansen, H., Knaevelsrud, C., Lüken, U., Wurm, S., Schneider, S., \& Brakemeier, E.-L. (2021). Mental health in times of the COVID-19 pandemic: Current knowledge and implications from a European perspective. European Psychologist, 26(4), 310-322. https://doi.org/10.1027/1016-9040/a000465 (Supplemental)

World Health Organization (2021, February 18). WHO coronavirus disease (COVID19) dashboard. World Health Organization. https://covid19.who.int/

Wolverton, C., Guidry Hollier, B., \& Lanier, P. (2020). The Impact of computer selfefficacy on student engagement and group satisfaction in online business courses. Electronic Journal Of E-Learning, 18(2), 175-188. https://doi.org/10.34190/EJEL.20.18.2.006

Yan Z. (2020). Unprecedented pandemic, unprecedented shift, and unprecedented opportunity. Hum Behav \& Emerg Tech, 2(2), 110-112. https://doi.org/10.1002/hbe2.192

Zhoc, K. C. H., Webster, B. J., King, R. B., Li, J. C. H., \& Chung, T. S. H. (2019). Higher education student engagement scale (HESES): development and psychometric evidence. Research in Higher Education, 60(2). https://doi.org/10.1007/s11162-018-9510-6

\section{Appendix A}

Demographic Questionnaire

Instructions: At this part, you are asked to provide some general information about yourself. Please answer all the questions either by filling in the spaces or ticking the boxes which apply to you.

1. Age:

2. Gender:
a. Female
b. Male
c. Prefer not to say
d. Other 
3. Cumulative Index $(\mathrm{Cl})$ or overall Grade Point Average (GPA):

4. Major
a. Psychology
b. Marketing
c. Communication
d. Int. Tourism \& Hospitality Management
e. Informational Technology
f. Undecided
g. Other

5. Year of Study
a. Freshman (0-29 credits, first year of study)
b. Sophomore (30-59 credits, second year of study)
c. Junior (60-89 credits, third year of study)
d. Senior (90+ credits, fourth year of study)

6. How many courses are you currently enrolled in?
a. 1
b. 2
c. 3
d. 4
e. 5

7. How many people from each category live with you at home? (one response per line)

\begin{tabular}{|l|l|l|l|l|l|l|}
\hline & 0 & 1 & 2 & 3 & 4 & 5 \\
\hline Mother / stepmother / foster mother & & & & & & \\
\hline Father / stepfather / foster father & & & & & & \\
\hline Brother(s) (including stepbrother) & & & & & & \\
\hline Sister(s) / (including stepsister) & & & & & & \\
\hline Grandparent(s) & & & & & & \\
\hline Friend(s) / flat mate(s) & & & & & & \\
\hline Romantic partner & & & & & & \\
\hline Other & & & & & & \\
\hline
\end{tabular}

8. How do you usually connect in your online courses?
a. Desktop/laptop computer with webcam
b. Desktop/laptop computer without webcam
c. Tablet
d. Smartphone

9. You have been diagnosed with a learning disability:
a. Dyslexia
b. ADHD
c. Other
d. No

\section{Appendix B}

\section{Online Student Engagement Scale (OSE) (Dixson, 2015)}

Instructions: Within a course, how well do the following behaviors, thoughts, and feelings describe you? Please answer using the following 5-point scale. Keep in mind that there are no right or wrong answers, just personal views and experiences. 1 Not at all characteristic of me; Not really characteristic of me; 3 Moderately characteristic of me; 4 Characteristic of me; 5 Very characteristics of me. 
1. Making sure to study on a regular basis

2. Putting forth effort

3. Staying up on the readings

4. Looking over class notes between getting online to make sure I understand the material

5. Being organized

6. Taking good notes over readings, PowerPoints, or video lectures

7. Listening/reading carefully

8. Finding ways to make the course material relevant to my life

9. Applying course material to my life

10. Finding ways to make the course interesting to me

11. Really desiring to learn the material

12. Having fun in online chats, discussions or via email with the instructor or other students

13. Participating actively in small-group discussion forums

14. Helping fellow students

15. Getting a good grade

16. Doing well on the exams/assessments

17. Engaging in conversations online (chat, discussions, email)

18. Posting in the discussion forum/ MS Teams chat regularly

19. Getting to know other students in the class

\section{Appendix C}

Technical Difficulties Questionnaire (created based on Banna et al. 2015) Instructions: During an online class, how often do you experience the following issues? Please respond using the following 7-point Likert scale. Keep in mind that there are no right or wrong answers, just personal views and experiences. 1: Never; 2: Very Rarely; 3: Rarely; 4: Occasionally; 5: Frequently; 6: Very Frequently; 7 Always.

1. My computer running slowly

2. My computer crashing

3. Losing internet connection

4. Slow internet connection

\section{Appendix D}

Distractions at Home Questionnaire (based on Chhetri, 2020) Instructions: Within an online course, how often do you experience the following issues? Please respond using the following 7-point Likert scale. Keep in mind that there are no right or wrong answers, just personal views and experiences. 1: Never; 2: Very Rarely; 3: Rarely; 4: Occasionally; 5: Frequently; 6: Very Frequently; 7: Always.

1. Family members or other people living with me (roommate, friend, romantic partner) distract me from classes / assignments /studying /exams

2. My phone (social media, applications) distracts me from classes / assignments / studying

3. My surroundings at home distract me (TV, pets, loud noises) 


\section{Appendix E}

Computer Self-Efficacy Scale (Dang et al., 2016)

Instructions: Using the scale below, please respond to each statement by indicating to what extend you agree or disagree. Keep in mind that there are no right or wrong answers, just personal views and experiences. 1: Strongly Disagree; 2: Disagree; 3: Somewhat disagree; 4: Neutral; 5: Somewhat Agree; 6: Agree; 7: Strongly Agree.

1. I enjoy using computers

2. I am confident about using computers

3. In general, I am comfortable with using computers and software applications

\section{Appendix F}

Open Ended Questions

Instructions: In your own experience, please answer the following questions. Keep in mind that there are no right or wrong answers, just personal views and perceptions.

1. Name something that you find challenging in online courses.

2. Name something that you enjoy in online courses. 